\title{
Pengembangan LKPD Berbasis Open-Ended Kelas XI SMA pada Tahapan Pleminary Research
}

\author{
Nova Anggraini ${ }^{*}{ }^{*}$, Zulfah $^{2}$ \\ ${ }_{1,2}$ Universitas Pahlawan Tuanku Tambusai \\ ${ }^{*}$ nova10anggraini11@gmail.com
}

\begin{abstract}
Abstrak
Penelitian ini merupakan penelitian pengembangan lembar kerja peserta didik dengan menggunakan model ADDIE. Subjek dalam penelitian ini adalah siswa kelas XI SMA/MA dan objek penelitian adalah LKPD matematika berbasis Open Ended. Penelitian yang penulis lakukan ini menghasilkan LKPD berbasis Open Ended yang valid, praktis, efektif dan mampu memfasilitasi kemampuan pemahaman konsep peserta didik SMA/MA. Jenis penelitian yang digunakan adalah penelitian pengembangan (research and development) dengan model penelitian yaitu model ADDIE. Tujuan dari penelitian pengembangan LKPD ini untuk memfasilitasi kemampuan pemahaman konsep peserta didik dan menjadi bahan ajar tambahan untuk pendidik. Hasil pengembangan LKPD diharapkan mampu memfasilitasi kemampuan pemahaman konsep peserta didik dalam proses pembelajaran matematika, memperkaya pengetahuan, dan dapat memotivasi peserta didik dalam mempelajari matematika.
\end{abstract}

Kata Kunci: LKPD; Pendekatan Open Ended; Transformasi Geometri

\begin{abstract}
This research is a research development of student worksheets using ADDIE model. The subjects in this study were high school / MA grade XI students and the object of research was the Open Ended Mathematics LKPD. This research by the author produces Open Ended LKPD based on valid, practical, effective and able to facilitate the ability to understand the concept of high school / MA students. The type of research used is research and development with the research model, the ADDIE model. The purpose of this LKPD development research is to facilitate the ability to understand students' concepts and provide additional teaching material for educators. The results of the development of LKPD are expected to be able to facilitate the students' understanding of concepts in the process of learning mathematics, enrich knowledge, and can motivate students to learn mathematics.
\end{abstract}

Keywords: LKPD, Open decision ends; Geometry Transformation

\section{Pendahuluan}

Pembelajaran merupakan serangkaian kegiatan yang secara sadar telah terencana, dengan adanya perencanaan yang baik akan mendukung pengajaran, yang pada akhirnya juga akan meningkatkan kualitas pendidikan (Andi Prastowo, 2011). Matematika adalah salah satu mata pelajaran yang sangat penting dalam dunia pendidikan, karena pelajaran matematika dapat membuat peserta didik berfikir logis, rasional, kritis, dan luas, pernyataan ini sejalan dengan tujuan pendidikan nasional, yaitu : mempersiapkan anak didik agar mampu menghadapi perubahan dalam dunia yang senantiasa berubah, bertindak atas dasar pemikiran logis, rasional, kritis, dana gara anak didik mampu menggunakna matematika dalam kehidupan sehari-hari dan dalam mempelajari berbagai ilmu pengetahuan (Astuti \& Nurhidayah, 2017). 
Berdasarkan hasil pengamatan dilapangan peneliti menyimpulkan bahwa belum tersedia Lembar Kerja Peserta Didik (LKPD) sebagai media pembelajaran untuk pelajaran matematika. Pada gambar 1 merupakan bukti sekolah sudah menyediakan buku cetak matematika, namun buku tersebut hanya berisi materi-materi dan soal yang masih monoton dan tidak sesuai dengan kebutuhan peserta didik. Kebutuhan peserta didik yang dimaksud adalah dalam buku tersebut tidak terdapat aktivitas belajar peserta didik yang melibatkan peserta didik secara langsung dalam menemukan dan memahami konsep dari materi yang dipelajari.

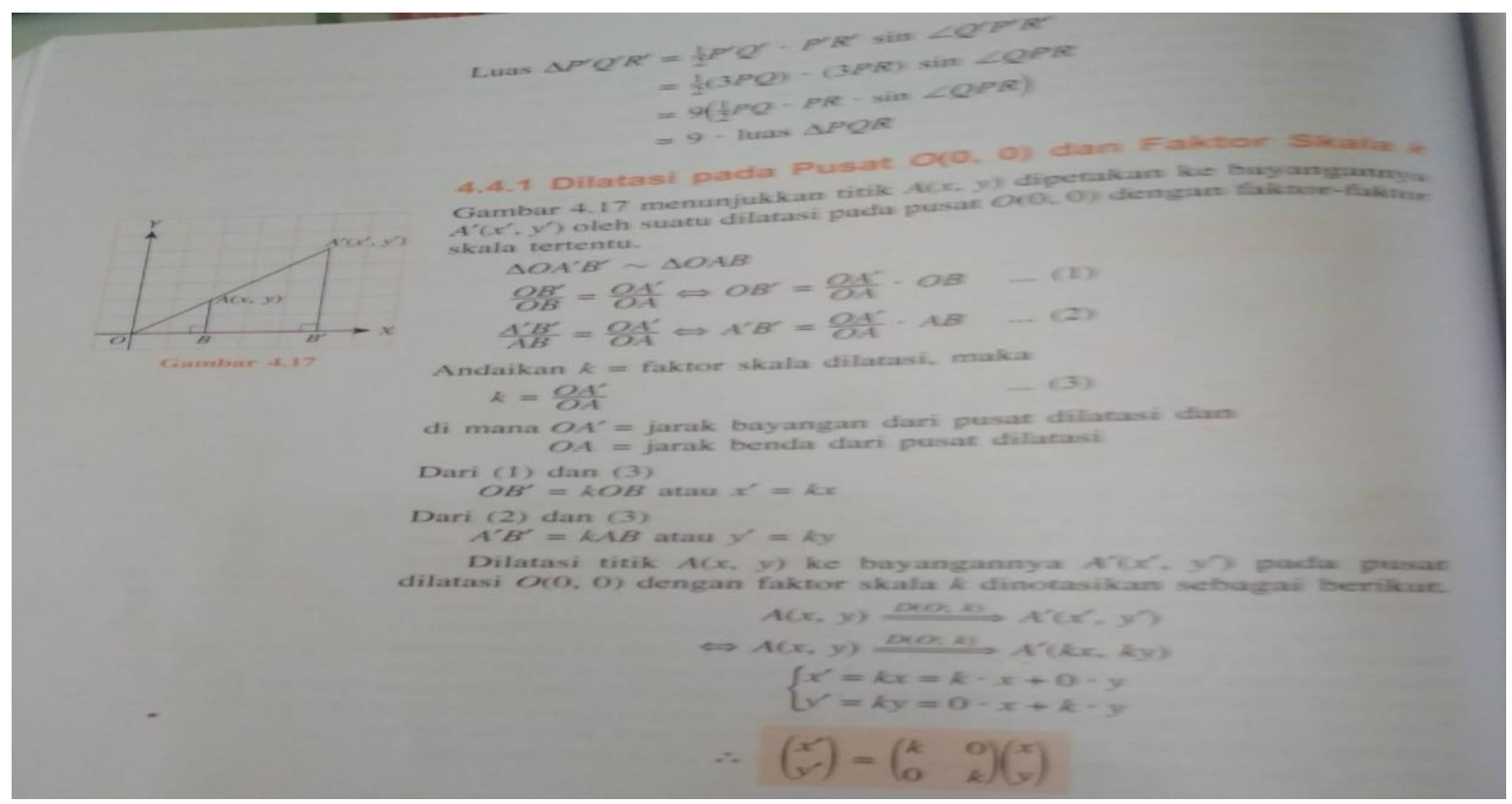

\section{Gambar 1. Materi Transformasi Geometri}

Menurut Shimada dalam (Sulianto,2011) pembelajaran dengan menggunakan Open Ended dimulai dari memberi masalah terbuka dan masalah tersebut dapat membawa siswa untuk menyelesaikan dengan berbagai macam penyelesaian (yang benar), sehingga dapat memicu kemampuan kecerdasan berdasarkan pengalaman peserta didik dalam proses pembelajaran. Penelitian ini menghasilkan bahan ajar berupa LKPD berbasis open-ended. LKPD yang dibuat berisi tentang masalah-masalah berbasis openended. Dalam pembelajaran matematika dengan menggunakan kurikulum 2013, menuntut guru untuk secara professional merancangpembelajaran efektif dan bermakna, salah satu prosedur yang harus dilakukan guru membuat pembelajaran efektif dan bermakna adalah mengaktifkan peserta didik (Mulyasa, 2013). Sesuai dengan fungsinya, 
LKPD dapat menjadikan pembelajaran di kelas menjadi efektif dan bermakna.Jenis masalah yang digunakan dalam pembuatan LKPD berbasis open-ended adalah masalah yang non rutin dan bersifat terbuka. Menurut Risman (2011) masalah open ended dikelompokan menjadi dua bagian, yaitu (1) Soal-soal yang mempunyai solusi tunggal dengan banyak strategi penyelesaian. (2) Soal-soal yang mempunyai banyak solusi dan juga banyak strategi penyelesaian.

\section{Metode Penelitian}

Jenis penelitian yang digunakan adalah penelitian pengembangan (research and development). R\&D adalah rangkaian proses atau langkah-langkah dalam rangka mengembangkan suatu produk baru atau menyempurnakan produk yang telah ada agar dapat dipertanggungjawabkan (Sugiyono, 2011). Model penelitian yang digunakan adalah model ADDIE. Benny (2009) menyatakan bahwa salah satu model desain sistem pembelajaran yang memperlihatkan tahapan-tahapan dasar desain sistem pembelajaran yang sederhana dan mudah dipelajari adalah model ADDIE. Sesuai dengan namanya, terdiri daari lima fase atau tahap utama yaitu, (A)nalysis, (D)esign, (D)evelopment, (I)mplementation, dan (E)valuation.Kelima fase atau tahap dalam model ADDIE, perlu dilakukan secara sistemik dan sistematik. Model desain sistem pembelajaran ADDIE dengan komponen-komponen dapat diperlihatkan pada tabel berikut.

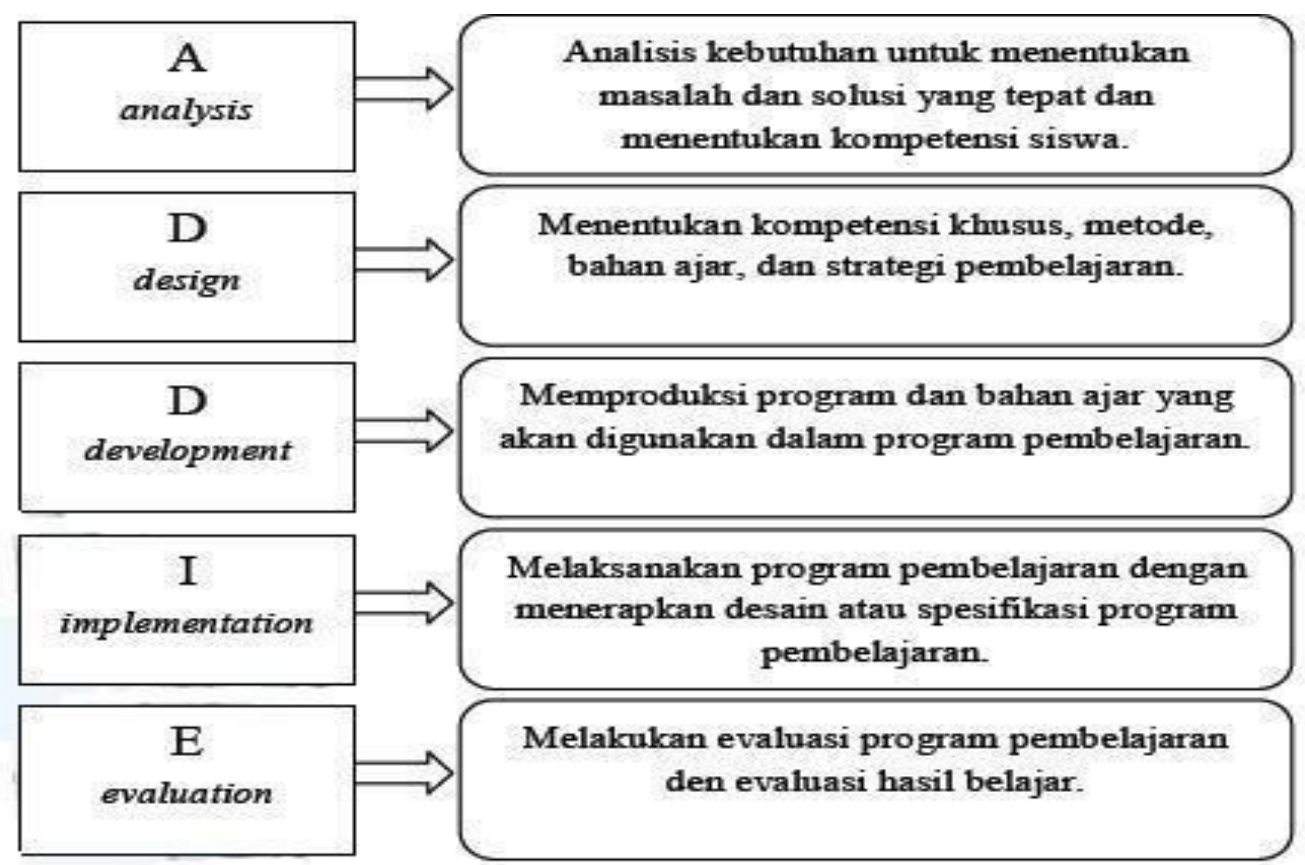

Gambar 2. Model ADDIE 
Angket evaluasi ahli teknologi dan ahli materi akan diperoleh saran dan kritik perbaikan terhadap LKPD yang telah dihasilkan. Selain itu, akan diperoleh pula penilaian terhadap LKPD sesuai dengan pernyataan yang ada dalam angket. Penilaian tersebut akan diberi skor untuk menentukan kevalidanLKPD, dapat dilihat pada tabel 1.

Tabel 1.Skor Angket AhliTeknologi dan Materi

\begin{tabular}{|c|c|c|}
\hline Jenis Pernyataan & Tanggapan & Skor \\
\hline \multirow{5}{*}{ Pernyataan positif } & Sangat setuju & diberi skor 5 \\
\hline & Setuju & diberi skor 4 \\
\hline & Cukup setuju & diberi skor 3 \\
\hline & Tidak setuju & diberi skor 2 \\
\hline & $\begin{array}{c}\text { Sangat tidak } \\
\text { setuju }\end{array}$ & diberi skor 1 \\
\hline
\end{tabular}

Sumber: (Yuni:2010)

Dari angket respon pendidik dan peserta didik, masing-masing akan diperoleh penilaian dan respon untuk setiap pernyataan dalam angket. Penilaian dan respon tersebut akan diberi skor dan dipersentasekan berdasarkan aspeknya.

Tabel 2. Skor Angket Peserta Didik

\begin{tabular}{|c|c|c|}
\hline \multirow{2}{*}{$\begin{array}{c}\text { Jenis } \\
\text { Pernyataan }\end{array}$} & Tanggapan & Skor \\
\hline \multirow{4}{*}{$\begin{array}{c}\text { Pernyataan } \\
\text { positif }\end{array}$} & Sangat setuju & diberi skor 5 \\
\cline { 2 - 3 } & Setuju & diberi skor 4 \\
\cline { 2 - 3 } & Cukup setuju & diberi skor 3 \\
\cline { 2 - 3 } & Tidak setuju & diberi skor 2 \\
\hline
\end{tabular}

Pemahaman peserta didik terhadap pemahaman konsep peserta didik tentang baris dan deret ditunjukkan melalui skor yang diperoleh peserta didik setelah mengikuti tes pemahaman konsep dengan menggunakan rubrik penilaian seperti pada tabel berikut. 
Tabel 3. Rubrik Penilaian Tingkat Pemahaman Konsep

\begin{tabular}{|c|c|c|}
\hline Indikator & Rubrik Penilaian & Skor \\
\hline \multirow{3}{*}{$\begin{array}{l}\text { Menyatakan ulang suatu } \\
\text { konsep }\end{array}$} & a. Tidak menjawab & 0 \\
\hline & $\begin{array}{l}\text { b. Menyatakan ulang suatu konsep } \\
\text { tetapi salah }\end{array}$ & 1 \\
\hline & $\begin{array}{l}\text { c. Menyatakan ulang suatu konsep } \\
\text { dengan benar }\end{array}$ & 2 \\
\hline \multirow{3}{*}{$\begin{array}{l}\text { Mengklasifikasik an objek } \\
\text { menurut sifat tertentu sesuai } \\
\text { dengan konsepnya. }\end{array}$} & a. Tidak menjawab & 0 \\
\hline & $\begin{array}{l}\text { b. Mengklasifikasikan objek } \\
\text { menurut sifat tertentu tetapi tidak } \\
\text { sesuai dengan konsepnya }\end{array}$ & 1 \\
\hline & $\begin{array}{l}\text { c. Mengklasifikasikan objek } \\
\text { menurut sifattertentu sesuai dengan } \\
\text { konsepnya }\end{array}$ & 2 \\
\hline \multirow{3}{*}{$\begin{array}{l}\text { Memberi contoh dan non } \\
\text { contoh dari konsep. }\end{array}$} & a. Tidak menjawab & 0 \\
\hline & $\begin{array}{l}\text { b. Memberi contoh dan non contoh } \\
\text { tetapi salah }\end{array}$ & 1 \\
\hline & $\begin{array}{l}\text { c. Memberi contoh dan non contoh } \\
\text { dengan benar }\end{array}$ & 2 \\
\hline \multirow{3}{*}{$\begin{array}{l}\text { Menyajikan konsep dalam } \\
\text { berbagai bentuk representasi } \\
\text { matematika }\end{array}$} & a. Tidak menjawab & 0 \\
\hline & $\begin{array}{l}\text { b. Menyajikan konsep dalam } \\
\text { berbagai bentuk representasi } \\
\text { matematika tetapi salah }\end{array}$ & 1 \\
\hline & $\begin{array}{l}\text { c. Menyajikan konsep dalam } \\
\text { berbagai bentuk representasi } \\
\text { matematika dengan benar }\end{array}$ & 2 \\
\hline \multirow{3}{*}{$\begin{array}{l}\text { Mengembangkan syarat perlu } \\
\text { dan syarat cukup suatu konsep. }\end{array}$} & a. Tidak menjawab & 0 \\
\hline & $\begin{array}{l}\text { b. Mengembangkan syarat perlu dan } \\
\text { syarat cukup suatu konsep tetapi } \\
\text { salah }\end{array}$ & 1 \\
\hline & $\begin{array}{l}\text { c. Mengembangkan syarat perlu dan } \\
\text { syarat cukup suatu konsep dengan } \\
\text { benar }\end{array}$ & 2 \\
\hline \multirow{3}{*}{$\begin{array}{l}\text { Menggunakan, memanfaatkan, } \\
\text { dan memilih prosedur atau } \\
\text { operasi tertentu }\end{array}$} & a. Tidak menjawab & 0 \\
\hline & $\begin{array}{l}\text { b. Menggunakan, memanfaatkan, } \\
\text { dan memilih prosedur atau operasi } \\
\text { tertentu tetapi salah }\end{array}$ & 1 \\
\hline & $\begin{array}{l}\text { c. Menggunakan, } \\
\text { memanfaatkan, dan memilih } \\
\text { prosedur atau operasi tertentu } \\
\text { dengan benar }\end{array}$ & 2 \\
\hline \multirow{2}{*}{$\begin{array}{l}\text { Mengaplikasikan konsep atau } \\
\text { algoritma pada pemecahan } \\
\text { masalah }\end{array}$} & a. Tidak menjawab & 0 \\
\hline & $\begin{array}{l}\text { b.Mengaplikasikan konsep atau } \\
\text { algoritma padapemecahan masalah } \\
\text { tetapi salah }\end{array}$ & 1 \\
\hline
\end{tabular}

Sumber: (Sartika:2011). 
Pada tahap analisis kurikulum dilakukan telaah terhadap kurikulum yang digunakan yaitu Kurikulum 2013. Analisis tersebut bertujuan untuk mengetahui tujuan, isi materi kelas XI SMA/MA yang akan dikembangkan serta untuk mengetahui kemampuan yang harus dimiliki oleh peserta didik setelah mempelajari materi tersebut. Analisis ini berupa penentuan indikator dari materi, Penjabaran KI, KD dan indikator pencapaian kompetensi menjadi pertimbangan untuk menentukan konsep-konsep yang diperlukan dalam pembelajaran matematika dan mengukur pencapaian KI dan KD.

Angket digunakan peneliti dalam menganalisa peserta didik untuk mengetahui kualitas individual peserta didik yang merupakan telaah dari kebutuhan peserta didik dan dapat dijadikan petunjuk dalam perancangan perangkat pembelajaran yang akan dibuat. Hal yang dilakukan adalah melihat kecendrungan belajar, karakteristik peserta didik dalam berpikir, dan keterampilan peserta didik dalam belajar serta ketertarikan peserta didik dalam menggunakan LKPD. Analisis ini dijadikan sebagai pertimbangan dalam merancang LKPD berbasis PBL. Sedangkan Analisis konsep bertujuan untuk mengidentifikasi konsep-konsep utama yang diajarkan, merinci dan menyusunnya secara sistematis untuk mencapai indikator-indikator pencapaian kompetensi

Teknik pengumpulan data yang digunakan dalam penelitian ini adalah wawancara dan tes. Wawancara dilakukan dengan guru pada saat tahap analisis. Wawancara dilakukan untuk mendapatkan data tentang karakteristik peserta didik, informasi mengenai materi dan startegi atau metode yang digunakan ketika pembelajaran berlangsung, sertapendapat guru mengenai bahan ajar seperti LKPD yang digunakan. Tesadalahsekumpulansoal matematika dengan memperhatikan kemampuan pemahaman konsep peserta didik dalam mengolah soal yang diberikan. Hasilteskemudiandianalisis untukmemperolehdatayangdiharapkan.

\section{Hasil Penelitian dan Pembahasan}

Analisis pendahuluan dilakukan pada peserta didik kelas XI SMA dan MA. Hasil dari tahap analisis terbagi menjadi hasil analisis kebutuhan, hasil analisis peserta didik, analisis kurikulum, serta analisis konsep. Analisis pendahuluan dilaksanakan untuk memperoleh informasi mengenai permasalahan yang terdapat pada lapangan sebenarnya. Selain itu melalui analisis pendahuluan, peneliti memperoleh gambaran 
sementara dari produk yang dikembangkan. Analisis pendahuluan dilakukan melalui beberapa tahap sebagai berikut.

\section{Hasil Analisis Kebutuhan}

Untuk mendapatkan data, peneliti mengumpulkan informasi dengan cara mengobservasi pelaksanaan kegiatan pembelajaran, mewawancarai guru matematika kelas XI SMA/MA dan memberikan angket kepada peserta didik mengenai permasalahan yang biasa timbul dalam perangkat pembelajaran matematika sehingga perlu untuk mengembangkannya. Dari hasil analisis kebutuhan ini peserta didik membutuhkan LKPD yang dapat memfasilitasi mereka untuk berpartisipasi aktif dalam mengkonstruksi pengetahuannya dan meningkatkan pemahaman yang berkaitan dengan dunia nyata. Peserta didik menginginkan LKPD yang menarik berciri khas budaya melayu Riau, mudah dipahami dan penjelasan materinya terperinci serta permasalahan yang dipakai dalam LKPD terkait persoalan matematika dalam konteks kehidupan sehari-hari.

\section{Analisis Kurikulum}

Pada tahap ini dilakukan telaah terhadap kurikulum 2013 untuk mata pelajaran matematika kelas XI SMA/MA. Analisis ini menjadi pedoman dalam melakukan pengembangan perangkat pembelajaran LKPD Berbasis Open ended. Analisis untuk Kompetensi dasar materi ini adalah dikembangkannya indikator dengan menggunakan pembelajaran Open ended untuk mengorganisasikan materi dan menentukan tujuan pembelajaran yang ingin dicapai pada setiap pertemuan. Semua indikator yang dirancang telah disesuaikan dengan $\mathrm{KD}$ dan indikator pemahaman konsep namun tidak lepas dari konten kehidupan nyata serta budaya melayu Riau.

Hasil penjabaran indikator pembelajaran untuk kompetensi inti pengetahuan pada materi Transformasi Geometri yang diujicobakan dapat dilihat pada tabel 4. 
Tabel 4. Kompetensi Dasar dan Indikator Pembelajaran

\begin{tabular}{|c|c|}
\hline Kompetensi Dasar & Indikator pembelajaran \\
\hline $\begin{array}{l}\text { 1.1 Menghargai dan menghayati ajaran } \\
\text { agama yang dianutnya. } \\
\text { 2.2 Memiliki rasa ingin tahu, percaya } \\
\text { diri, dan ketertarikan } \\
\text { padamatematika serta memiliki rasa } \\
\text { percaya pada daya dan kegunaan } \\
\text { matematika, yang terbentuk melalui } \\
\text { pengalamanbelajar. } \\
\text { 3.9 Memahamikonseptransformasi } \\
\text { (translasi, refleksi, rotasi, dan } \\
\text { dilatasi) dengan menggunakan } \\
\text { objek-objek geometri. } \\
\text { 4.6 Menerapkan prinsip transformasi } \\
\text { (translasi, refleksi, rotasi, dan } \\
\text { dilatasi) dalam pemecahkan } \\
\text { permasalahan nyata. }\end{array}$ & $\begin{array}{l}\text { 1.1.1 Siswa dapat menjawab kodrat } \\
\text { Allah bahwa semua makhluk di } \\
\text { dunia berpindah tempat dan selalu } \\
\text { berkembang menurut kodratnya. } \\
\text { 2.2.2 Siswa dapat menjelaskan apa yang } \\
\text { dimaksud refleksi. } \\
\text { 3.9.1 Siswa dapat mencerminkan benda } \\
\text { terhadap garis. } \\
\text { 3.9.2 Siswa dapat mencerminkan titik } \\
\text { terhadap garis. } \\
\text { 3.9.3 Siswa dapat mencerminkan titik } \\
\text { pada bidang koordinat. } \\
\text { 3.9.4 Siswa dapat mencerminkan bangun } \\
\text { datar geometri pada bidang } \\
\text { koordinat. } \\
\text { 4.6.1 Siswa dapat menentukankan } \\
\text { bayangan suatu titik atau bangun } \\
\text { geometri dari Komposisi } \\
\text { transformasi. }\end{array}$ \\
\hline
\end{tabular}

\section{Analisis peserta didik}

Dari hasil analisis peserta didik diketahui bahwa peserta didik memiliki kemampuan yang heterogen, sehingga tingkat pengetahuan peserta didik ada yang pengetahuan rendah, pengetahuan sedang, dan pengetahuan tinggi. Saat pembelajaran beberapa peserta didik yang berkemampuan rendah banyak membutuhkan bimbingan langsung dari gurunya. Lebih cendrung pasif saat proses pembelajaran berlangsung. Peserta didik berkemampuan sedang dapat menerima penjelasan dari guru dan mereka lebih cenderung bertanya dan berdiskusi dengan teman dari pada bertanya kepada guru secara langsung. Sedangkan peserta didik yang berkemampuan tinggi dapat menerima penjelasan guru serta dapat memberikan komentar dengan bahasanya sendiri terkait masalah yang diberikan. Namun dalam menyelesaikan suatu permasalahan, peserta didik 
dari kemampuan tinggi sampai kemampuan rendah rata-rata terlihat masih kebingungan dan kesulitan dalam memahami dan menyelesaikan soal permasalahan yang berbentuk cerita dalam kehidupan nyata yang berkaitan dengan transformasi geometri. Sehingga perlu mengembangkan bahan ajar yang dapat memfasilitasi kebiasaan dan mengakomodasi karakter yang dimiliki peserta didik dalam meningkatkan keterampilan dalam menyelesaikan permasalahan sehari-hari yang mereka khususnya kemampuan pemahaman konsep matematis.

Berdasarkan karakteristik yang telah dipaparkan, peneliti merasa perlu adanya pengembangan LKPD berbasis Open ended. LKPD berbasis Open endedmerupakan LKPD yang dapat memfasilitasi peserta didik dalam pemahaman konsep pelajaran. Hal ini sejalan dengan kurikulum 2013 yang sedang berlaku saat ini menganjurkan adanya aktivitas aktif siswa dalam proses pembelajaran (Permendikbud, 2014). Dalam kurikulum 2013, proses pembelajaran menjadi kunci utama dalam implementasinya (Kusumangtyas, 2013). Implementasi kurikulum 2013 khususnya pada pembelajaran Matematika, siswa dituntut untuk dapat lebih aktif dalam menemukan hal-hal yang baru dan dapat menyelesaikan ataupun menyimpulkan setiap permasalahan yang diberikan.

Selain itu, Pemilihan Open ended ini didasari karena merupakan model pembelajaran yang membantu guru untuk mengaitkan materi dengan situasi nyata peserta didik. Oleh sebab itu, LKPD berbasis Open ended ini merupakan salah satu bahan ajar yang dapat digunakan guru untuk membantu peserta didik menemukan suatu konsep sekaligus meningkatkan kemampuan pemahaman konsep dan aktivitas peserta didik dalam proses pembelajaran.

\section{Analisis Konsep}

Analisis konsep bertujuan untuk menentukan isi dan materi pelajaran yang dibutuhkan dalam pengembangan LKPD yang akan dihasilkan, dengan cara mengidentifikasi konsep-konsep utama yang diajarkan, merinci dan menyusunnya secara sistematis sesuai dengan urutan penyajiannya. Materi sangat diperlukan untuk mencapai indikator pencapaian kompetensi. Setelah mengetahui materi yang dipelajari di kelas XI SMA/MA, maka diperlukan analisis konsep. Peneliti mengambil materi transformasi geometri, hal ini didasarkan karena peserta didik cenderung kurang menyukai materi tersebut. Tidak adanya media pembelajaran yang secara khusus membantu merupakan salah satu alasan dari peserta didik yang kurang menyukai materi tersebut. Materi transformasi geometri memuat permasalahan yang mungkin banyak ditemui peserta didik 
dalam kehidupan sehari-hari dan peserta didik diharapkan mampu untuk menyelesaikan masalah tersebut.

\section{Simpulan}

Pembelajaran di SMA dan MA sudah menggunakan kurikulum 2013, bahan ajar yang digunakan hanya buku paket yang disediakan oleh sekolah, sedangkan bahan ajar seperti LKPD jarang digunakan dalam proses pembelajaran. LKPD yang sering dijumpai di sekolah-sekolah belum sesuai dengan kebutuhan dan karakteriktik siswa terutama dalam menstimulasi kemampuan pemahaman konsep matematis peserta didik, model pembelajaran Open ended dapat menstimulasi kemampuan pemahaman konsep matematis peserta didik. Peserta didik masih merasa kesulitan dalam menyelesaikan soal yang berkaitan dengan transformasi geometri. Dengan demikian penelitian ini menyimpulkan bahwa perlu dikembangkan adanya bahan ajar matematika yang berupa Lembar Kerja Peserta Didik (LKPD) berbasis Open ended yang dapat menstimulus kemampuan pemahaman konsep peserta didik.

\section{Referensi}

Andi, Prastowo. (2011). Panduan Kreatif MembuatBahan Ajar Inovatif. Yogyakarta: Express.

Astuti.,Sari,Nurhidayah. (2017). Pengembangan Lembar Kerja Sisiwa (LKS) Pada Mata Pelajaran Matematika Siswa Kelas X SMA. Jurnal Cendikia. Volume 1, No.2

Kemendikbud. (2014). Permendikbud No.58 Tahun 2014 tentang Tujuan Pembelajaran Matematika. Jakarta: Kementrian Pendidikan dan Kebudayaan RI.

Kusumaningtyas, Atut. (2013). Pengaruh Kolaborasi Strategi Pembelajaran Circ Dan Quick On The Draw Terhadap Hasil Belajar Pada Siswa KelaS IV SD Negeri Bogotanjung, Pati Tahun 2012/2013. Skripsi thesis, Universitas Muhammadiyah Surakarta.

Mulyasa. (2013). Pengembangan dan Implementasi Kurikulum 2013.Bandung : PT Remaja Rosdakarya

Novri, U. N., Zulfah, Astuti. (2018). Pengaruh Strategi REACT (Realiting,Experiencing, Applying, Cooperating, Transfering) Terhadap Kemampuan Pemahaman Konsep Matematis Peserta Didik Kelas VII SMP Negeri 1 Bangkinang. Jurnal Cendikia. Volume 2, No.2

Risman, M. S. (2011). Pengaruh Pendekatan Open Ended Terhadap Kemampuan Pemecahan Masalah Matematis. Skripsi. Universitas Bandung

Sugiyono. (2011). Metode Penelitian Kuantitatif, Kualitatif dan R \& D. Bandung: Alfabeta. 
Sulianto. (2011).Keefektifan Model Pemebelajaran Kontekstual dengan Pendekatan Open Ended dalam Aspek Penalaran dan Pemecahan Masalah pada Materi Segitiga di Kelas VII. Jurnal Phytagoras Volume 1, No.1

Yuni, Yamasari. (2010). Pengembangan media Pembelajaran Matematika Berbasis ICT yang Berkualitas. Surabaya : Seminar Nasional Pascasarjana X-ITS. 4 Agustus 2010 . 